ISRAEL

\title{
Exploiting an advantage
}

Nechemia Meyers learns of the likely prospects for science and technology under Israel's new government

"WE in the Likud realise that resourcepoor Israel has a comparative economic advantage in only one spherescience and technology-and so we will do everything we can to ensure that this advantage is exploited to the fullest possible extent". So says Professor Moshe Arens, the unofficial science spokesman for Israel's new Likud Government.

The Likud's concern with science and technology may stem in part from the fact that it has four men with a technological background in its 45member Knesset delegation. Apart from Arens they are Professor Joseph Rom of the Haifa Technion's Department of Aeronautical Engineering, Mr Gustav Badian, Secretary-General of the Engineers' Union, and Mr Yitzhak Moday, who has a degree in chemical engineering but specialises in economic subjects.

The Likud does not favour the establishment of a separate Ministry of Science and Technology, however. This, it believes, would be counterproductive. "Instead of pigeonholing these subjects", declares Arens, "we must ensure that every single ministry is concerned with science and technology, and particularly with exploiting Israel's own technological potential."

In the defence sphere, for example, Arens readily admits that in present circumstances Israel would still be dependent on certain American components, but argues that if there should be an American embargo on the supply of these components, they could be purchased elsewhere or produced at home. He points with pride to the fact that Israel's highly effective missiles, which he helped to develop, have brought in tens of millions of export dollars, and he is certain that many more high-technology civilian products could do the same.

"We are already selling a whole range of sophisticated items ranging from pharmaceuticals and laboratory chemicals to computerised whole body scanners for hospitals and computerised design systems for textiles", he says. "But much remains to be done. Take solar energy, a field in which we have pioneered. Even now Israel uses more solar energy per capita than any other country in the world, and she also sells some solar energy installations overseas. However, if our scientists are given proper encouragement, I'm convinced that they will be able to develop more efficient methods of exploiting solar energy".

According to press reports, Arens may be put in charge of a ministry or an authority dealing with energy, water, building and other elements of what he calls the country's physical infrastructure. While refusing to comment on these reports, he does stress the Likud's view that the development of Israel's physical infrastructure must be more carefully planned, and its component parts utilised in a more rational manner.

Arens promises that Israel's R\&D facilities, whether in agriculture, industry or some other sphere, will get all the support they require both from the Likud government and from private investors, whom the Likud believes it can encourage by creating a better climate for investment. However, the universities, which are almost entirely dependent on public funds, may be in for a tough time-after already suffering a drop of $30 \%$ in real income since 1973.

While Arens declines to estimate how much support the universities can expect, he does note that the Likud will have to slash the government budget if it is to reduce inflation (now running at over $40 \%$ a year). This means that at least for the next few years "short term targets will have to be given priority over longer-term targets". Being a faculty member himself, Arens doesn't lack sympathy for Israel's institutions of higher learning. But his presentation of the Likud's priorities gives them clear cause for concern.

\section{Publish and be dammed}

In the continuing debate over Britain's energy policy there is still no shortage of information being published. Chris Sherwell reports

WHILE final preparations were being made for the opening of the Windscale inquiry this week, one of the chief opponents of the controversial project was with impeccable timing publishing a new book seriously questioning Britain's commitment to an electronuclear future. It was not the only publication on the energy front, however. The UK Department of Energy (DEN) was busily announcing another set of findings regarding its strategy for developing alternative energy sources, this time for tidal power and particularly the Severn barrage. Four reports were published on this matter alone. The DEN also released a review, prepared at the end of last year, detailing the country's energy policy options.
The inquiry into British Nuclear Fuel Ltd's (BNFL) application to develop land at Windscale for an oxide fuel processing plant was due to open on Tuesday morning in nearby Whitehaven, Cumbria, before $\mathrm{Mr}$ Justice Parker, the inspector, and two assessors, Sir Edward Pochin and Professor Sir Frederick Warner. BNFL submitted an outline planning application to the local authorities in February. In accordance with his announcement last December, $\mathrm{Mr}$ Peter Shore, Secretary of State for the Environment, ordered the public inquiry to allow examination of health, safety, environmental and planning aspects.

The inquiry, which is expected to last some three months, is widely regarded as a critical test for the future of nuclear power in Britain. On it also hangs the fate of deals worth hundreds if not thousands of millions of pounds for reprocessing other countries' ir- radiated oxide fuel. BNFL's statement of case, circulated in May, emphasises the conservation and waste control benefits of reprocessing and the economic advantages of taking on overseas business. Opponents, who include Friends of the Earth, the Conservation Society and others, have retained expensive legal counsel and sought to raise funds publicly.

The inquiry was expected to begin with brief opening statements on behalf of BNFL and the various opponents before proceeding later in the week to BNFL's detailed presentation. The basis for the sort of arguments the corporation will then face is contained in The Fissile Society by the FOE's energy specialist, Walt Patterson, and published last week*. With the inquiry almost certain to spill beyond the immediate issue of the reprocessing plant itself, the book is a useful articulate distillation of the case against a nuclear future that neatly ties together a historical perspective and the prevailing sense of urgency.

No such urgency is apparent in 